\title{
ASSESSMENT OF MOUNTAIN ECOSYSTEMS CHANGES UNDER ANTHROPOGENIC PRESSURE IN LATORICA RIVER BASIN (TRANSCARPATHIAN REGION, UKRAINE)
}

\author{
OLENA KOZAK, YAKIV DIDUKH
}

National University of “Kyiv-Mohyla Academy”, Skovorody St., 2, Kyiv, 04070, Ukraine; e-mail: kosako@ukr.net National Academy of Sciences of Ukraine, Kholodny Institute of Botany, Tereschenkivska 2, Kyiv, 01601, Ukraine; e-mail: didukh@mail.ru

\begin{abstract}
Kozak O., Didukh Y.: Assessment of mountain ecosystems changes under anthropogenic pressure in Latorica river basin (Transcarpathian region, Ukraine). Ekológia (Bratislava), Vol. 33, No. 4, p. $365-379,2014$.

The Carpathian mountain ecosystems have been changed under anthropogenic pressure during last decades. The different types of anthropogenic pressure affect the ecosystem characteristics and functioning. The species composition, species richness and ecological indicator values of 12 ecological factors were compared among 14 habitats: natural, semi-natural, degraded and ruderal ecosystems in different altitude zones. The results show that anthropogenic pressure and altitude gradient influence indices of edaphic and climate conditions. The anthropogenic pressure also affects biodiversity: the highest species richness and Shannon-Wiener index are observed in habitats with 'intermediate' disturbances level, while high level of disturbances cause decrease in biodiversity. The disturbances cause the ecosystem to become susceptible to invasion of alien species, while native species, especially rare, become vulnerable and can disappear.
\end{abstract}

Key words: altitude gradient, ecological indicator values, biodiversity.

\section{Introduction}

The Carpathian Mountains represent Europe's largest continuous forest ecosystem supporting the natural biodiversity. This region has a large proportion of rare and endemic species and is biodiversity hotspot (CEI, 2001; Bálint et al., 2011). Altitudinal variation, the diversity of microclimates and geologic substrates presented by the mountainous terrain have led to an extraordinary range of habitats and species. Approximately 2,000 plant species are catalogued from the Ukrainian Carpathians, representing more than $40 \%$ of the flora of Ukraine. Almost $20 \%$ of Ukraine's forests are located in the Carpathian Mountains. The native forests include Fagus sylvatica, Abies alba, Picea abies, Acer platanoides, A. pseudoplatanus, Carpinus betulus, Fraxinus excelsior, Quercus robur, Q. petraea, Tilia cordata, T. platyphyllos, Ulmus glabra (Standovar, Kenderes, 2003; USAID, 2001).

However, human activities and irrational logging have caused a substantial damage to the Carpathian forests. Long periods of forest exploitation have led to rapid conversion of 
forest into settlements, farmlands, industrial-mining sites and infrastructure. Large areas of forest were cut down, leading to ecosystem fragmentation. Furthermore, artificial spruce monoculture was established in beech forest zone. The monoculture caused massive loss of spruce and forest degradation due to its lesser resistance to pests, diseases and windfalls (Kalutsky, 2008; Krynytsky, Kramarets, 2009; Usckiy, 2010). The forests were clearly overexploited during the Soviet Union period, with annual production of the timber - as much as 38.0 million tones - considered to be unsustainable by the WWF (Bennett, 2000). During transition period, the main problem was illegal logging. Legal and illegal extraction of forest products, both wood and non-timber products, have become a vital source of income and subsistence for local people (Bihun, 2005). The development of main railways had additional consequences for biodiversity because it facilitated introduction of alien species into native habitats (Turnock, 2002). On the other hand, strengthening of industrialisation and urbanisation processes caused farmland abandonment. Abandoned farmlands may revert back to forests (Kuemmerle et al., 2008; Rudel et al., 2005) and this process may also allow forest biodiversity to recover (Bowen et al., 2007; Chazdon, 2008).

In this article, we consider ecosystem changes along the altitude gradient caused by anthropogenic disturbances. The aim of this study is to assess different types of anthropogenic pressure on mountain ecosystems based on comparison of species composition, species richness and ecological indicator values of 12 ecological factors in natural, semi-natural, degraded and ruderal ecosystems in different altitude zones.

\section{Objects and methods}

\section{Study region}

The study area is situated in Latorica river basin from $48.360 \mathrm{~N}-22.590 \mathrm{E}$ to $48.750 \mathrm{~N}-23.170 \mathrm{E}$ (coordinates in decimal degree) located in the Eastern Carpathian Mountains, Transcarpathian region of Western Ukraine (Fig. 1). Its source is near the village Latirka in the Ukrainian Carpathians. It flows from Ukraine (156.6 km) to Slovakia $(31.4 \mathrm{~km}), 188 \mathrm{~km}$ in total. The whole catchment area of the river Latorica is $31,289 \mathrm{~km}^{2}$. The area is a typical mountain landscape with altitudes from 100 to $1600 \mathrm{~m}$ a.s.l. and includes the Transcarpathian lowland (100-200 $\mathrm{m})$, lower mountain (200-400 m), middle mountain (400-800 m), upper mountain (800-1200 m), and subalpine (1100-1600) zones with geologically old soils (Bihun, 2005). The highest mountain is Stoy, with altitude of 1681 $\mathrm{m}$. The bedrock is largely dominated by sandstone and shale (Denisiuk, Stoyko, 2000; Augustyn, 2004), but some andesite-basalts occur in the southwest of the study area (Herenchuk, 1981). The mountain part of Latorica river basin is characterised by brown mountain-forest stony soils in complex with clay their types, rare by sod-burozem and mountain-meadow soils. The plain part is characterised by sod-podzolic loam soils and clay their types, rare by meadow soils. The foothills part is characterised by burozem-podzolic soils and clay their types (National Atlas of Ukraine, 2008).

Agricultural lands cover $31 \%$ of the total territory of the river basin and $67 \%$ is covered with forests. Climate is mild, with annual average temperature of $9.3^{\circ} \mathrm{C}$ and annual precipitation of $752 \mathrm{~mm}$ in the lowland, and $6.5^{\circ} \mathrm{C}$ and $998 \mathrm{~mm}$ in the mountain zones, respectively (Herenchuk, 1981).

\section{Selection and analyses of sampling sites}

The study sites were pre-selected according to a subjective estimation of their degradation status by evaluation of human impact effect on changes in species composition. The pre-selection was then evaluated during field trips yielding the final set of sample sites. According to this evaluation, the following habitat types have been determined in the Latorica river basin of Ukrainian Carpathian Mountains (Figs 2, 3): 


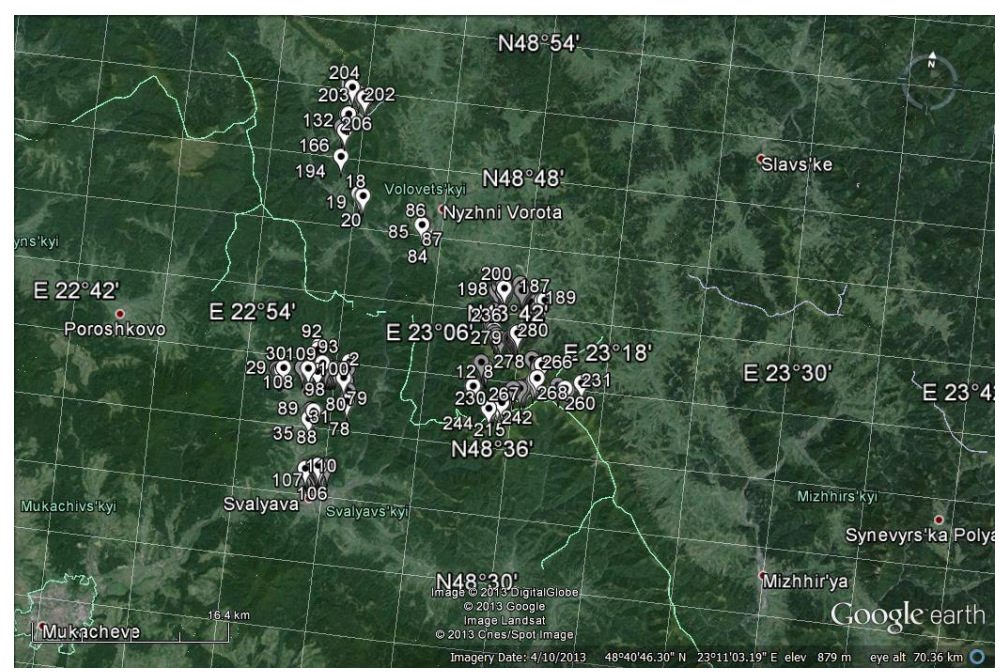

Fig. 1. Study sites in the Transcarpathian region of Western Ukraine.

- In subalpine zone (1100-1600 m a.s.l.):

1. Natural subalpine meadows (MS) are characterised by the lowest anthropogenic transformation; the vegetation cover is undestroyed, and species composition is rich and diverse. The typical species are: Rhodococcum vitis-idaea, Vaccinium uliginosum, V. myrtillus, Luzula luzuloides, Thymus alpestris, Huperzia selago, Antennaria dioica, Ligusticum mutellina, Laserpitium latifolium, Homogyne alpina, Potentilla aurea. The following plant communities are represented: Loiseleurio-Vaccinietea and Calluno-Ulicetea.

2. Degraded subalpine meadows under recreation pressure (MSr) are characterised by destroyed and sparse vegetation cover, presence of litter and bare ground cover, species composition is poor, and is characterised mainly by grasses: Deschampsia caespitosa, Carex leporina, Agrostis tenuis, Festuca ovina, Nardus stricta. Rhodococcum vitis-idaea, Vaccinium myrtillus and Luzula luzuloides tolerate the recreation pressure. Vegetation in this habitat type belongs to the class Calluno-Ulicetea.

3. Degraded subalpine meadows after fire (MSf) are characterised by destroyed and sparse vegetation cover and poor species composition. Epilobium angustifolium, Hypericum montanum, Vaccinium myrtillus, Deschampsia caespitosa and Potentilla erecta are most commonly occurring species. The vegetation type is presented by class Calluno-Ulicetea, Epilobietea angustifolii.

4. Subalpine forests (FS) are distributed in altitudes $1192-1677 \mathrm{~m}$ a.s.l. The tree layer is sparse, and is represented mainly by Picea abies. The herb layer is represented by typical forest species: Oxalis acetosella, Rhodococcum vitis-idaea, Vaccinium myrtillus. This vegetation is ordered to the class Vaccinio-Piceetea.

- The beech forest zone is presented by two subzones: beech-coniferous and beech forests. In beech-coniferous subzones (800-1200 $\mathrm{m}$ a.s.l.):

5. Natural beech-coniferous forests (FB-Cn) are characterised by native tree species and absence of human impact. The origin of these forests is natural. The canopy openness is less than $20 \%$. These forests have very high productivity. The tree layer is represented by Fagus sylvatica, Picea abies, Acer pseudoplatanus. The herb layer is characterised by Oxalis acetosella, Mercurialis perennis, Dryopteris carthusiana, Rubus serpens, Mycelis muralis, Vaccinium myrtillus, Athyrium distentifolium and other species. The plant communities belong to the class Querco-Fagetea.

6. Semi-natural beech-coniferous forests (FB-Csn) are seriously degraded by cutting, but can be regenerated naturally. They are characterised by presence of juvenile trees. The forest stand is formed mainly by Picea abies, involving Salix caprea. The herb layer is represented by Rubus serpens, Athyrium distentifolium, Fragaria vesca, Agrostis tenuis, Hieracium pilosella, Anthoxanthum odoratum, Festuca ovina, Potentilla erecta. This vegetation is ordered to the class Vaccinio-Piceetea. 
7. Degraded beech-coniferous forests after cutting (FB-Cd) are characterised by absence of full forest stand, large amount of litter, the presence of seedlings of Picea abies, Salix caprea, and shrubs such as Sambucus racemosa, S. nigra, as well as herbs Rubus serpens, Athyrium distentifolium, Rubus idaeus, Salvia glutinosa, Agrostis tenuis, Epilobium angustifolium, Hypericum perforatum, Tussilago farfara, Brachypodium sylvaticum. This vegetation represents the classes Epilobietea angustifolii and Galio-Urticetea.

8. Secondary pasture meadows, which were formed in place of beech-coniferous forests ( $\mathrm{Mp}$ [FB-C]), are dominated mainly by herbs and grasses Agrostis tenuis, Anthoxanthum odoratum, Festuca ovina, Hieracium pilosella, Nardus stricta, Potentilla erecta, Trifolium repens, Hypochoeris radicata, Prunella vulgaris, Thymus pulegioides, Achillea submillefolium, Centaurea jacea, Cynosurus cristatus, Lotus corniculatus, Plantago lanceolata, Ranunculus acris, Taraxacum officinale, Trifolium prantense, Lolium perenne, Potentilla anserina, Bellis perennis. These plant communities are ordered to the Molinio-Arrhenatheretea class.

- In beech forest subzone (200-1000 $\mathrm{m}$ a.s.l.):

9. Natural beech forests (FBn) with native tree species and absence of human impact. The origin of these forests is natural. The canopy openness is less than $20 \%$. These forests have very high productivity. The tree layer is composed of Fagus sylvatica, Acer pseudoplatanus, A. platanoides, Fraxinus excelsior and Ulmus glabra. The shrub layer is composed of Daphne mezereum, Sambucus nigra. The dominant herb species are Lunaria rediviva, Scopolia carniolica, Symphytum cordatum, Asarum europaeum, Dryopteris filixmas and Galeobdolon luteum. These communities are classified within the class Querco-Fagetea.

10. Modified beech forests (FBm) with lower level of disturbances, such as recreation or selective cutting. The tree layer is formed by Carpinus betulus and Fagus sylvatica, and the herb layer is dominated by Aposeris foetida, Galeobdolon luteum, Luzula luzuloides, Maianthemum bifolium, Mycelis muralis, Rubus serpens, Stellaria holostea. These plant communities are of the Querco-Fagetea class.

11. Semi-natural beech forests (FBsn) are seriously degraded by cutting, but can be regenerated naturally. They are characterised by presence of juvenile trees. The tree layer is composed of Betula pendula, Populus tremula, 
Carpinus betulus and herb layers are composed of Achillea submillefolium, Agrostis tenuis, Centaurea jacea, Cruciata glabra, Festuca ovina, Fragaria vesca, Stenactis annua, Tanacetum vulgare, Solidago virgaurea, Lysimachia vulgaris. These plant communities are ordered to the class Querco-Fagetea.

12. Secondary hay meadows, which were formed in place of beech forests $(\mathrm{Mh})$, are represented mainly by herbs such as Achillea submillefolium, Agrostis tenuis, Centaurea jacea, Betonica officinalis, Briza media, Festuca pratensis, Galium verum, Hypericum perforatum, Leucanthemum vulgare, Lotus corniculatus, Peucedanum oreoselinum, Pimpinella saxifraga, Plantago lanceolata, Ranunculus acris, Trifolium alpestre, T. pratense and Veronica chamaedrys. The described plant communities represent classes Molinio-Arrhenatheretea and Trifolio-Geranietea.

13. Secondary pasture meadows formed in place of beech forests (Mp [FB]), are represented mainly by herbs and grasses, such as Achillea submillefolium, Agrostis tenuis, Anthoxanthum odoratum, Festuca ovina, Hieracium pilosella, Hypochoeris radicata, Lotus corniculatus, Plantago lanceolata, Potentilla erecta, Trifolium repens, Prunella vulgaris, Thymus pulegioides, Ranunculus acris, Taraxacum officinale, Trifolium prantense, Lolium perenne, Potentilla anserina, Bellis perennis. This vegetation belongs to the Molinio-Arrhenatheretea class.

14. Ruderal habitats (R) are characterised by dominance of alien and apophytic species, such as Ambrosia artemisiifolia, Artemisia vulgaris, Echinocystis lobata, Helianthus tuberosus, Heracleum sosnowskyi, Polygonum cuspidatum, Rubus caesius, Solidago serotina, Stenactis annua, Urtica dioica, Tanacetum vulgare and Clematis vitalba. This vegetation represents the classes Galio-Urticetea and Artemisietea vulgaris.

Twenty plots in each habitat type have been analysed. The total number of study sites contains 280 plots. Each plot was rectangular in shape $\left(5 \times 5 \mathrm{~m}\right.$; Cutko, 2009). The terrain of study sites is flat $\left(0^{\circ}-10^{\circ}\right)$ or sloping $\left(10^{\circ}-40^{\circ}\right)$ and the altitude varies from 188 to $1677 \mathrm{~m}$ (Fig. 1). The description of each plot includes geographical coordinates, altitude, aspect, inclination, percentage cover of vascular plants, cryptogams, stones, bare ground and litter, vegetation height of trees, shrubs, grasses and herbs. Data sampling was performed in July and August of 2012.

\section{Data analysis}

The ecological indicator values considering the native plant species presence in study sites have been determined according to methods of Didukh (2011). Indicator values are based on ecological scales. The units in these scales are grades. The reflect amplitude characteristics of species, specified and evaluated based on field data. The ecological indexes include: soil humidity ( $\mathrm{Hd}=23$ grades), variability of damping ( $\mathrm{fH}=11$ grades), acidity ( $\mathrm{Rc}=15$ grades), total salt regime $(\mathrm{Sl}=19$ grades $)$, carbonate content in soil $(\mathrm{Ca}=13$ grades $)$, nitrogen content $(\mathrm{Nt}=11$ grades $)$, aeration of soil (Ae $=15$ grades $)$, temperature regime $(\mathrm{Tm}=17$ grades $)$, humidity $(\mathrm{Om}=23$ grades $)$, continentality $(\mathrm{Kn}=17$ grades $)$, cryo-climate $(\mathrm{Cr}=15$ grades $)$ and light in community $(\mathrm{Lc}=9$ grades $)$. Twelve ecological indices were evaluated using the software package Turboveg for Windows v. 2.98 for each studied site.

Species richness was determined as number of all vascular plant species per sampling plot used to assess species diversity in studied habitat groups. More aspects of diversity are characterised by evenness, which is emphasised by the Shannon-Wiener index $\left(\mathrm{H}^{\prime}=\Sigma P_{i} \ln P_{i}\right)$ called as a diversity (Peet, 1974; Krebs, 1978), where $P$ is the proportion of individuals that species $i$ contributes to the total $i$ abundance.

Cluster analysis was carried out using single linkage method and Euclidean distance as a similarity measure. Ordination analysis was performed to demonstrate relationships between ecological factors and habitat types. Pearson correlation analysis was used to determine the relationship between environmental factors. The analyses were performed using the software package SPSS Statistics 16.0, PC-ORD 5.33 and Statistica 6.0.

Nomenclature of vascular plants follows Mosyakin and Fedoronchuk (1999) and nomenclature of syntaxa follows Solomakha (2008).

\section{Results and discussion}

\section{Analysis of ecological factors}

The distribution of 12 ecological indices among studied sites is presented in Table 1. In relation to soil humidity $(\mathrm{Hd})$, all studied sites are characterised by mesophytic conditions with very narrow amplitude, corresponding to value range in 11.1-12.5 grades [amplitude $(\Delta)=$ 
$\mathrm{T}$ a b l e 1. Mean and standard deviation of 12 ecological factors depending on studied vegetation type. One-way ANOVA is conducted for all values. F values are presented; $d f 1=13 ; d f 2=266 ; p<0.0001 ; N=280$.

\begin{tabular}{|l|c|c|c|c|c|c|c|c|c|c|c|c|}
\hline & Hd & Fh & Rc & Sl & Ca & Nt & Ae & Tm & Om & Kn & Cr & Lc \\
\hline FB-Cn & $12.1 \pm 0.1$ & $3.7 \pm 0.5$ & $6.1 \pm 0.9$ & $5.8 \pm 0.4$ & $6.1 \pm 0.8$ & $5.3 \pm 0.3$ & $7.4 \pm 0.3$ & $7.6 \pm 0.7$ & $14.3 \pm 0.9$ & $6.9 \pm 0.4$ & $8.9 \pm 0.5$ & $4.1 \pm 0.5$ \\
\hline FBn & $12.0 \pm 0.2$ & $4.7 \pm 0.4$ & $8.0 \pm 0.6$ & $6.8 \pm 0.5$ & $7.5 \pm 0.6$ & $6.5 \pm 0.9$ & $7.1 \pm 0.5$ & $8.9 \pm 0.4$ & $13.4 \pm 0.7$ & $7.4 \pm 0.6$ & $9.1 \pm 0.6$ & $3.7 \pm 0.6$ \\
\hline FB-Csn & $11.8 \pm 0.3$ & $4.9 \pm 0.9$ & $5.3 \pm 0.7$ & $5.6 \pm 0.4$ & $5.5 \pm 0.7$ & $5.1 \pm 0.4$ & $6.9 \pm 0.5$ & $7.2 \pm 0.6$ & $14.3 \pm 0.9$ & $7.9 \pm 0.3$ & $8.0 \pm 0.3$ & $6.0 \pm 0.6$ \\
\hline FBm & $11.8 \pm 0.1$ & $4.9 \pm 0.2$ & $7.7 \pm 0.5$ & $6.5 \pm 0.2$ & $6.8 \pm 0.5$ & $5.9 \pm 0.4$ & $6.7 \pm 0.2$ & $9.1 \pm 0.3$ & $13.3 \pm 0.4$ & $6.9 \pm 0.4$ & $9.4 \pm 0.4$ & $3.7 \pm 0.4$ \\
\hline FBsn & $11.9 \pm 1.1$ & $6.0 \pm 0.8$ & $6.5 \pm 0.5$ & $6.5 \pm 0.3$ & $5.9 \pm 0.7$ & $4.9 \pm 0.6$ & $6.5 \pm 0.8$ & $8.3 \pm 0.4$ & $12.9 \pm 0.5$ & $8.2 \pm 0.4$ & $8.1 \pm 0.4$ & $6.7 \pm 0.6$ \\
\hline FB-Cd & $12.2 \pm 0.4$ & $5.8 \pm 0.9$ & $6.6 \pm 0.7$ & $6.1 \pm 0.6$ & $6.5 \pm 0.6$ & $5.9 \pm 0.7$ & $6.6 \pm 0.7$ & $8.4 \pm 0.5$ & $12.8 \pm 0.6$ & $8.4 \pm 0.5$ & $7.8 \pm 0.7$ & $6.3 \pm 0.7$ \\
\hline FS & $12.0 \pm 0.1$ & $4.1 \pm 0.2$ & $3.9 \pm 0.2$ & $4.7 \pm 0.2$ & $4.2 \pm 0.2$ & $4.6 \pm 0.1$ & $7.8 \pm 0.2$ & $6.7 \pm 0.2$ & $14.1 \pm 0.4$ & $8.2 \pm 0.2$ & $7.1 \pm 0.1$ & $5.5 \pm 0.2$ \\
\hline MS & $11.8 \pm 0.5$ & $4.9 \pm 0.4$ & $4.7 \pm 0.7$ & $4.9 \pm 0.4$ & $4.7 \pm 0.6$ & $4.4 \pm 0.4$ & $7.1 \pm 0.6$ & $6.6 \pm 0.6$ & $13.8 \pm 0.6$ & $8.2 \pm 0.4$ & $7.3 \pm 0.4$ & $6.2 \pm 0.5$ \\
\hline MSr & $12.5 \pm 0.5$ & $6.5 \pm 0.3$ & $5.5 \pm 0.7$ & $5.7 \pm 0.9$ & $4.7 \pm 0.6$ & $4.3 \pm 0.4$ & $7.6 \pm 0.9$ & $7.3 \pm 0.3$ & $13.2 \pm 0.5$ & $8.3 \pm 0.4$ & $7.5 \pm 0.5$ & $7.2 \pm 0.3$ \\
\hline MSf & $12.2 \pm 0.2$ & $5.1 \pm 1.0$ & $4.5 \pm 0.7$ & $4.9 \pm 0.5$ & $4.5 \pm 0.5$ & $4.4 \pm 0.3$ & $7.5 \pm 0.6$ & $7.2 \pm 0.5$ & $13.5 \pm 0.3$ & $8.2 \pm 0.4$ & $7.5 \pm 0.5$ & $6.2 \pm 0.7$ \\
\hline Mh & $11.1 \pm 0.4$ & $6.5 \pm 0.3$ & $7.3 \pm 0.4$ & $7.5 \pm 0.4$ & $7.1 \pm 0.5$ & $5.4 \pm 0.5$ & $6.3 \pm 0.3$ & $8.6 \pm 0.3$ & $12.1 \pm 0.4$ & $8.3 \pm 0.3$ & $8.6 \pm 0.3$ & $7.4 \pm 0.1$ \\
\hline Mp [FB-C] & $11.5 \pm 0.3$ & $7.3 \pm 0.3$ & $6.3 \pm 0.5$ & $6.7 \pm 0.8$ & $6.2 \pm 0.7$ & $5.0 \pm 0.6$ & $6.1 \pm 0.7$ & $7.9 \pm 0.5$ & $12.0 \pm 0.6$ & $8.2 \pm 0.3$ & $8.5 \pm 0.4$ & $7.4 \pm 0.1$ \\
\hline Mp [FB] & $11 . . \pm 0.5$ & $7.1 \pm 0.3$ & $7.0 \pm 0.4$ & $7.2 \pm 0.5$ & $6.9 \pm 0.5$ & $5.3 \pm 0.5$ & $6.2 \pm 0.4$ & $8.4 \pm 0.3$ & $11.8 \pm 0.5$ & $7.9 \pm 0.3$ & $8.7 \pm 0.2$ & $7.4 \pm 0.1$ \\
\hline R & $11.7 \pm 1.0$ & $6.4 \pm 0.8$ & $8.0 \pm 0.3$ & $8.3 \pm 0.4$ & $6.8 \pm 1.0$ & $6.4 \pm 0.6$ & $6.8 \pm 0.5$ & $9.1 \pm 0.9$ & $11.7 \pm 0.7$ & $8.5 \pm 0.6$ & $8.7 \pm 0.7$ & $7.2 \pm 0.3$ \\
\hline F & 11.038 & 68.125 & 94.037 & 87.900 & 58.412 & 38.513 & 19.020 & 57.411 & 42.306 & 31.591 & 49.129 & 177.750 \\
\hline
\end{tabular}

1.4]. The lowest soil humidity values were found in secondary hay meadow (Mh), and the highest - in degraded subalpine meadow (MSr). Therefore, this index varies depending on amount of precipitation along the altitude gradient. Thus, the humidity in the Carpathians is not a differentiating factor for forest communities. This is also confirmed by the fact that communities are characterised by a narrow range of soil aeration (Ae), 6.1-7.8 grades $(\Delta=$ 1.7), which correlates with soil humidity (Table 2). The sites FB-Csn, FBm, FB-Cd, Mp [FBC], Mp [FB], Mh and R are characterised by sub-aerophiles plant communities (50-80\%), and sites FB-Cn, FBn, MS, FS, MSr and MSf - by hemi-aerophobes (35-50\%). In this case, the lowest values were found in the pasture sites in condition of soil compaction, and the highest - in subalpine forests. In general indices of soil aeration have been reduced in sites under anthropogenic pressure, which is known to cause soil compaction.

The indices of variability of damping ( $\mathrm{fH}$ ) are described by wider amplitude from 3.7 to 7.3 grades $(\Delta=3.6)$. In particular, sites FB-Cn, FBn, MS, FS, FB-Csn, FBm are characterised

$\mathrm{T}$ a b l e 2. Pearson correlation coefficients between 12 ecological factors in mountain zone of Latorica river basin $\left({ }^{*} p<0.05 ;{ }^{* *} p<0.01\right.$; grey colour marks high value of correlation coefficient).

\begin{tabular}{|c|c|c|c|c|c|c|c|c|c|c|c|}
\hline & Fh & Rc & S1 & $\mathrm{Ca}$ & $\mathrm{Nt}$ & Ae & Tm & Om & Kn & $\mathrm{Cr}$ & Lc \\
\hline Hd & $-0.372^{* *}$ & $-0.200^{* *}$ & $-0.258^{* *}$ & $-0.376^{* *}$ & 0.011 & $0.700^{* *}$ & $-0.254^{* *}$ & $0.349^{* *}$ & -0.041 & $-0.322^{* *}$ & $-0.216^{*}$ \\
\hline Fh & 1 & $0.348^{* *}$ & $0.483^{* *}$ & $0.298^{* *}$ & -0.013 & $-0.614^{* *}$ & $0.333^{* *}$ & -0.714 & $0.376^{* *}$ & $0.141^{*}$ & $0.763^{\star *}$ \\
\hline $\mathrm{Rc}$ & & 1 & $0.854^{* *}$ & 0.894 & $0.754^{* *}$ & $-0.348^{* *}$ & $0.880^{*}$ & $-0.542 *$ & $-0.234^{* *}$ & $0.711^{* *}$ & -0.093 \\
\hline Sl & & & 1 & $0.778^{\star *}$ & $0.663^{* x}$ & $-0.311^{* *}$ & $0.759^{* *}$ & $-0.693^{* *}$ & 0.055 & $0.554^{* *}$ & $0.220^{* *}$ \\
\hline $\mathrm{Ca}$ & & & & 1 & $0.698^{* *}$ & $-0.447^{* *}$ & $0.809^{* *}$ & $-0.512 *$ & $-0.272^{* *}$ & $0.722^{* *}$ & -0.108 \\
\hline $\mathrm{Nt}$ & & & & & 1 & 0.016 & $0.734^{* *}$ & $-0.330^{* *}$ & $-0.152^{*}$ & $0.508^{* *}$ & $-0.299^{* *}$ \\
\hline $\mathrm{Ae}$ & & & & & & 1 & $-0.348^{* *}$ & $0.426^{* *}$ & -0.007 & $-0.376^{* *}$ & $-0.338^{* *}$ \\
\hline Tm & & & & & & & 1 & $-0.598^{* \prime \prime}$ & $-0.207^{* *}$ & $0.731^{* *}$ & -0.116 \\
\hline Om & & & & & & & & 1 & $-0.342^{* *}$ & $-0.285^{* *}$ & -0.517 \\
\hline Kn & & & & & & & & & 1 & $-0.673^{* *}$ & $0.703^{* \prime}$ \\
\hline $\mathrm{Cr}$ & & & & & & & & & & 1 & -0.335 \\
\hline
\end{tabular}


by hydrocontrastophobe plant communities, sites FBsn, FB-Cd, Mh, MSr, MSf, R - hemi-hydrocontrastophobes, and pasture sites (Mp [FB-C], Mp[FB]) - hemi-hydrocontrastophiles. The lowest values of variability of damping were defined in natural beech-coniferous forests, and the highest - in secondary pasture meadows which were formed in place of beech-coniferous forests. Therefore, the variability of damping increases under the influence of anthropogenic factors and pasture due to intensive evaporation processes, which indicate an important stabilising role of forest communities in the regulation of soil moisture.

The indices of soil acidity $(\mathrm{Rc})$ in studied sites vary widely: 3.9-8.0 grades $(\Delta=4.1)$, which corresponds to $\mathrm{pH}=4.0-7.0$, from acidic to neutral soils. The chemical properties of soil determine species differentiation in plant communities. In particular, subalpine habitats MS, FS and MSf are characterised by the most acid per-acidophile communities, the sites of beech-coniferous and partly beech forest and secondary meadow communities in their place (FB-Cn, FB-Csn, FBsn, FB-Cd, Mp [FB-C], Mp [FB], MSr and R) are characterised by acidophiles, and beech forests (FBn, FBm, Mh) - by sub-acidophiles. The highest values of soil acidity were defined for subalpine forests, and the lowest (neutral soil reaction) - for natural beech forests. In general, soil acidity decreases with altitude.

A similar regularity was defined for total salt regime (Sl). According to this index, studied ecosystems are also characterised by a rather wide amplitude, from 4.7 to 8.3 grades $(\Delta=$ 3.6). In particular, subalpine sites are characterised by the poorest semi-oligotrophes communities, sites FB-Cn, FBn, FB-Csn, FBm, FBsn, FB-Cd, Mp [FB-C] and MSr - mesotrophes, secondary meadow communities ( $\mathrm{Mp}[\mathrm{FB}], \mathrm{Mh}$ ) and ruderal habitats $\mathrm{R}$ - semi-eutrophes. The lowest indices of salt regime were recorded in subalpine forests, and the highest - in ruderal habitats. Consequently, the total salt content increases under anthropogenic pressure and with decrease in altitude.

The indices of carbonate content in soil $(\mathrm{Ca})$ in mountain part of Latorica river basin are characterised by a wide amplitude, $4.2-7.5$ grades $(\Delta=3.3)$, but carbonate outcrops are not present here. All subalpine sites MS, FS, MSr and MSf are characterised by carbonatophobes coenoses, and sites FB-Cn, FB-Csn, FBm, FBsn, FB-Cd, Mp [FB-C], Mp [FB] and $\mathrm{R}$ - hemi-carbonatophobes, while sites $\mathrm{FBn}$ and $\mathrm{Mh}$ are characterised by acarbonatophiles. So, the lowest indices of carbonate content are in subalpine forests, the highest - in natural beech forests.

The Carpathian brown soils are characterised by low content of mineral forms of nitrogen, because under acidic conditions, organics is converted into forms of humic acid. The indices of nitrogen content $(\mathrm{Nt})$ of studied sites are characterised by amplitude of 4.3-6.5 grades $(\Delta=2.2)$. In particular, sites MS, FS, FBsn, MSr and MSf are characterised by sub-anitrophiles communities, and sites FB-Cn, FBn, FB-Csn, FBm, FB-Cd, Mp [FB-C], Mp [FB], $\mathrm{Mh}$ and $\mathrm{R}-$ hemi-nitrophiles. Therefore, the lowest indices of nitrogen content are defined in degraded subalpine meadows under recreation pressure, where mineral compounds are mineralized or leached, and the highest - in natural beech forests with massive litter cover, which intensively decompose during 1 or 2 years.

Climatic factors in mountain regions, in contrast to the plain ones, are characterised by relatively wide amplitude, which significantly affects distribution of plant communities along the altitude gradient. The indices of temperature regime $(\mathrm{Tm})$ in studied habitats are character- 
ised by amplitude of 6.6-9.1 grades $(\Delta=2.5), 1256-1884 \mathrm{MJ} \cdot \mathrm{m}^{-2} \cdot \mathrm{year}^{-1}$. The natural subalpine communities MS and FS are characterised by microtherm conditions, the sites FB-Cn, FBn, FB-Csn, FBsn, FB-Cd, Mp [FB-C], Mp [FB], MSr and MSf - by sub-microtherm, and only FBm and $\mathrm{R}$ - by sub-mesotherm, which is typical for flat latitude. Thus, the indices of temperature regime change are affected by the altitude gradient and anthropogenic disturbances.

The humidity $(\mathrm{Om})$ reflects aridity-humidity of climate, or relation between precipitation and evaporation. Humidity indices increase along the altitude gradient from 11.7 to 14.3 grades $(\Delta=2.6)$. The sites of middle zone Mp [FB], FBsn, FB-Cd, Mp [FB-C], Mh and R are characterised by sub-aridophyte communities, where the level of precipitation is greater than evaporation. FB-Cn, FBn, FB-Csn, FBm, MS, FS, MSr and MSf sites are characterised by sub-ombrophyte coenosis, which reflects mountainous conditions. The lowest indices of humidity are observed in ruderal habitats, while the highest - in natural and semi-natural beech-coniferous forests.

The indices of continentality $(\mathrm{Kn})$, which reflect ocean and land effect on climate, are characterised by narrow amplitude from 6.9 to 8.5 grades $(\Delta=1.6)$, typical for hemi-oceanic $(110 \%-125 \%)$ conditions. The lowest indices of continentality are defined in natural and semi-natural beech-coniferous forests, and the highest - in ruderal habitats.

Indices of cryo-climate $(\mathrm{Cr})$, which reflect average winter temperature of soil, are characterised by amplitude in $7.1-9.1$ grades $(\Delta=2.3)$ in the studied sites. Thus negative average winter temperature varies between -2 and $-14^{\circ} \mathrm{C}$. The warmest winters (hemi-cryophytes) are recorded in natural and modified beech forests, and the coldest (sub-cryophytes) - in all other studied sites with minimum in subalpine zone. Quantitative cryo-climate indices change not only with altitude, but also with gradients of anthropogenic impact.

The indices of light in community (Lc) vary in amplitude from 3.7 to 7.4 grades $(\Delta=$ 3.7). The forest communities FB-Cn, FBn and FBm are characterised by scyophytes, the sites of degraded forests MS, FS, FB-Csn, FBsn, FB-Cd, MSf - by hemi-scyophytes, and meadow and ruderal habitats $\mathrm{Mp}$ [FB-C], Mp [FB], Mh, MSr and R - by sub-heliophytes. The lowest indices of light in community are defined in natural and modified beech forests, and the highest - in pasture and hay meadows.

The relation between environmental factors was defined based on correlation analysis (Table 2). In particular, the high linear correlation $(>0.7)$ was detected between soil humidity (Hd) and aeration (Ae), between acidity $(\mathrm{Rc})$, salt regime (Sl), carbonate content $(\mathrm{Ca})$ and nitrogen content $(\mathrm{Nt})$ in soil, which also correlate with indices of temperature regime $(\mathrm{Tm})$ and cryo-climate (Cr, Fig. 4). The negative correlation was detected between humidity (Om) and above mentioned factors. The correlation between main environmental factors and their influence on plant communities' distribution are presented in Fig. 4.

The scatterplots reflect relationship between environmental factors. In particular, differences in distribution between forest and meadow sites as well as altitude differentiation, become apparent when plotted in the coordinates of the soil acidity and salt regime ( $\mathrm{Rc} / \mathrm{Sl})$. In mountain forest zone, all forest sites are characterised by average degree of salinization in neutral or slightly alkaline reaction of soil solution, and meadow sites - by increasing of salt regime in the same reaction of soil solution. The scatterplot of salt regime and carbonate content in soil $(\mathrm{Sl} / \mathrm{Ca})$ reflects the similar tendency regarding differences between 

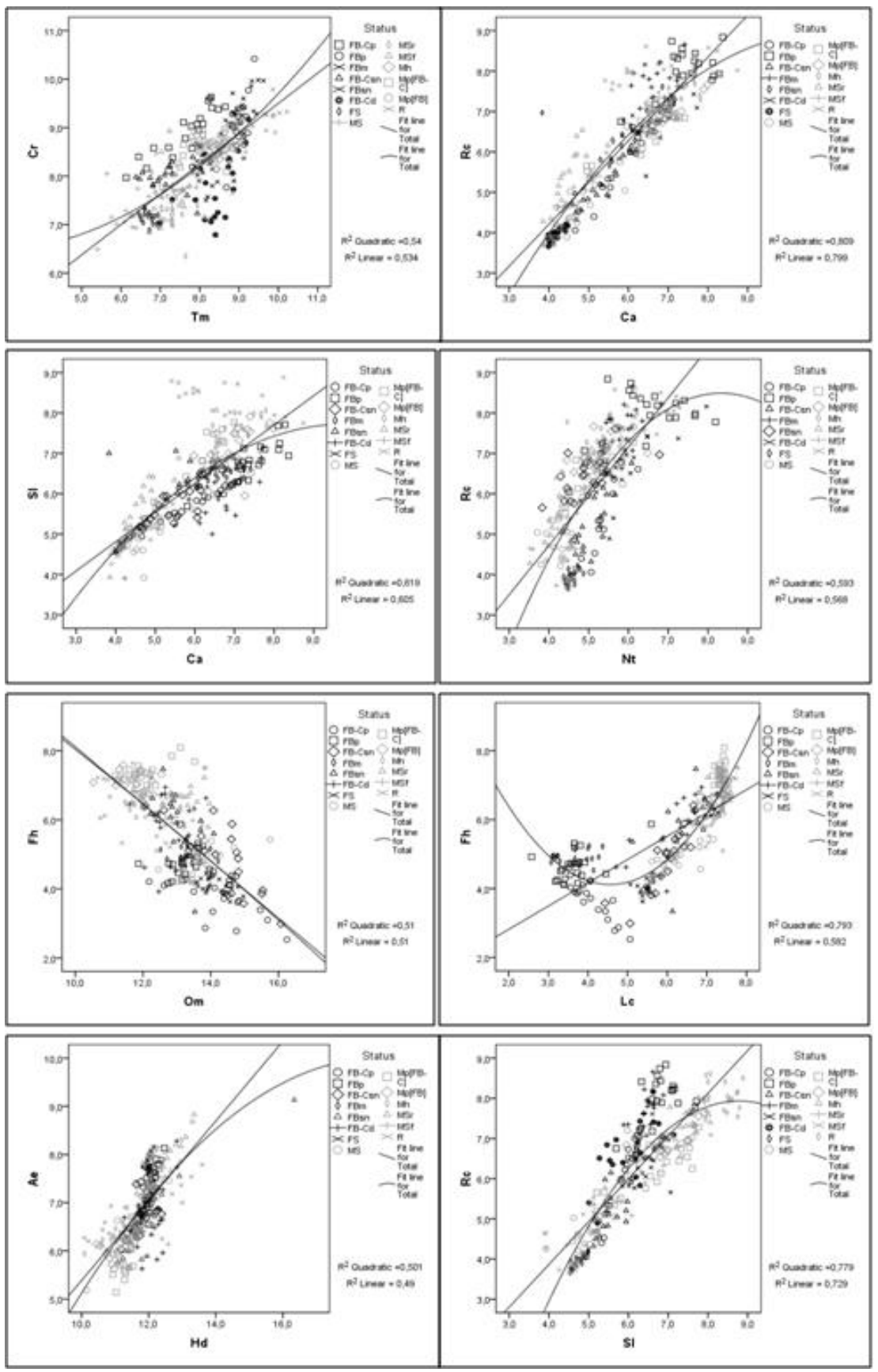

Fig. 4. Scatterplots between main environmental factors with high correlation. 
meadow and forest communities, but altitude distribution is less represented. Between indices of soil acidity and carbonate content (Rc/ $\mathrm{Ca})$ linear correlation is observed: while carbonate content in soil increases, the reaction of soil solution changes from acid to neutral. All studied sites in these coordinates of environmental factors are distributed along the altitude gradient, however the difference between forest and meadow communities was not as pronounced. The similar tendency was observed for distribution of plant communities in coordinates of soil acidity and nitrogen content $(\mathrm{Rc} / \mathrm{Nt})$, soil aeration and humidity $(\mathrm{Ae} / \mathrm{Hd})$, cryo-climate and temperature regime $(\mathrm{Cr} / \mathrm{Tm})$.

Between indices of variability of damping and humidity (fH/Om), variability of damping and light in community ( $\mathrm{Lc} / \mathrm{fH})$ negative correlations were detected. The differentiation between forest and meadow communities is observed in regards to these indices: the forests are characterised by wet conditions, while soil moisture is constant, and, on the contrary, meadow communities are characterised by lower indices of humidity while variability of damping increases. The forest communities are characterised by evaporation decreasing at lower indices of light, while in meadow communities, conversely, the light increase with increase in indices of variability of damping. However, a clear differentiation of data on environmental factors along the altitude gradient was not established.

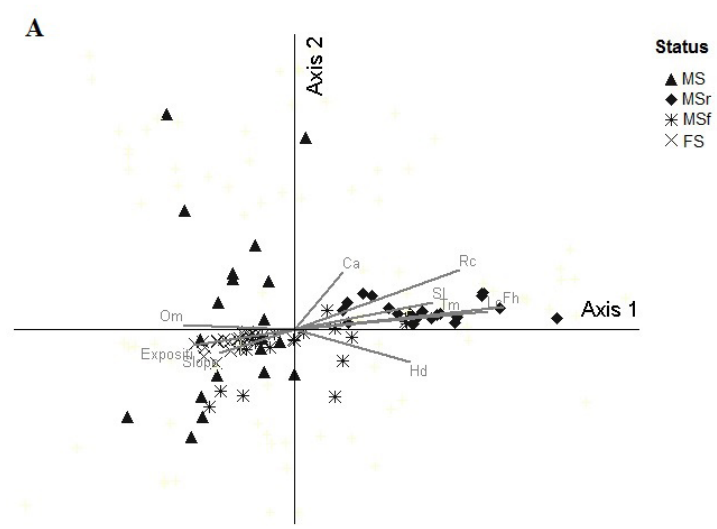

B
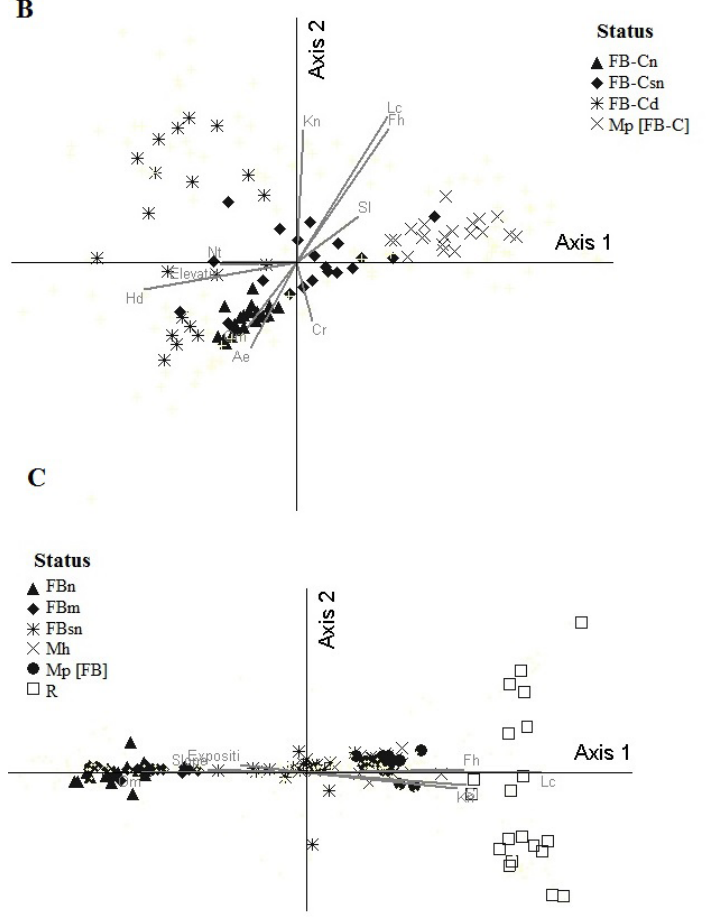

Fig. 5. Detrended correspondence analysis (DCA) diagram of the ordination of all species percentage cover data at studied plots in relation to environmental variables: $\mathrm{A}$ - in subalpine zone; $\mathrm{B}$ - in beech-coniferous forest subzones; $\mathrm{C}$ - in beech forest subzone. 
Detrended correspondence analysis (DCA) ordination revealed correlation between species percentage cover data and sample plots characters based on 12 ecological indicators, altitude, exposition and slope (Fig. 5). In subalpine zone (Fig. 5A), the natural MS and FS plots are clustered mainly in left segment of first axis area with environmental indicator of slope and exposition and humidity $(\mathrm{Om})$. The MSf plots are located in the middle of ordination axes. The MSr plots are concentrated in right part of first axis with environmental indicator of Ca, Rc, Sl, Tm, Lc and Fh. In beech-coniferous subzone (Fig. 5B) the natural FB-Cn plots are concerted in left segment of first axis area with environmental indicator of Om and Ae. The semi-natural FB-Csn plots are located in central part of diagram. The degraded FB-Cd plots are located in left part of first axis also and are correlated with $\mathrm{Nt}, \mathrm{Hd}$ and elevation. The $\mathrm{Mp}[\mathrm{FB}-\mathrm{C}]$ plots are concentrated in right segment of first axis. In beech forest subzone (Fig. 5C) FBn and FBm plots are again located to left part of the first ordination axes and are positively correlated with $\mathrm{Om}, \mathrm{Sl}$ and exposition. Cutting down forest (FBsn) is located in the middle of ordination axes. Open meadows ( $\mathrm{Mh}, \mathrm{Mp}[\mathrm{FB}]$ ) are located on the right part of diagram. Ruderal habitats $(\mathrm{R})$ have separate left position on the plot. In general, DCA reflect regularity that along first axis, from left to right, plots are located in accordance with succession stages and disturbances level: from natural to disturbed.

\section{Analysis of floristic diversity changes}

The highest species richness was recorded in meadow sites $\mathrm{Mh}$ and $\mathrm{Mp}[\mathrm{FB}]->20$ species per $25 \mathrm{~m}^{2}$, the lowest - in sites FB-Cd, FS, MSf, Mp[FB-C] and $\mathrm{R}-<7$ species (Fig. 5A). The similar tendency is observed for Shannon-Wiener index (Fig. 5B). The species richness and Shannon-Wiener index are lower in forest sites and increase in meadow communities, but high anthropogenic disturbances reduce these indices. Species richness in forest communities are two times lower than in meadow communities, which can be explained by presence of tree species and canopy openness affecting herb layer.
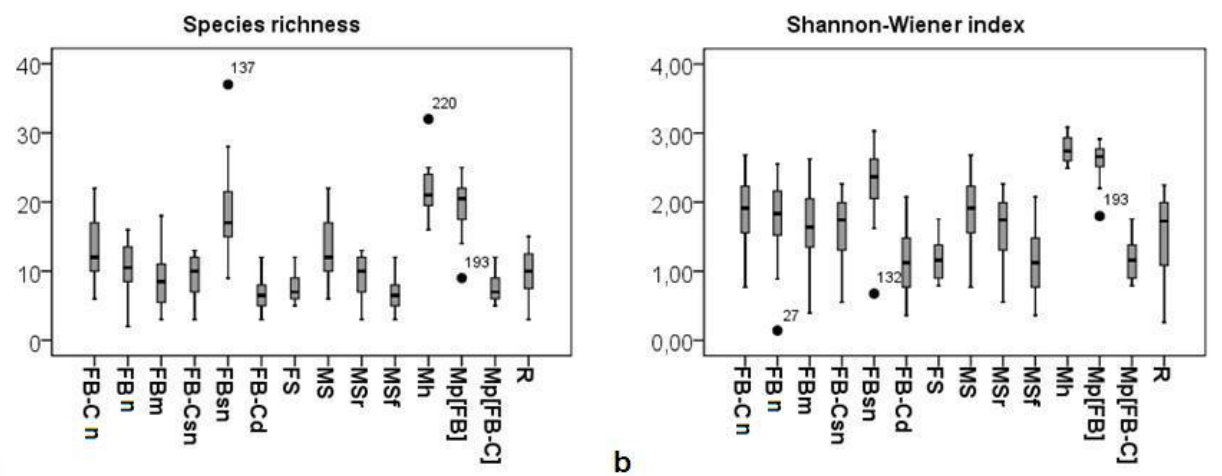

Fig. 6. The values of diversity indexes (Species richness and Shannon-Wiener index) in studied vegetation type in mountain zone in Latorica river basin . 
Under the anthropogenic pressure the ratio between different plant groups can be changed (Fig. 6). In particular, the rare plant species are observed in sites MS, FB-Cd, $\mathrm{FBn}$ and $\mathrm{Mh}$. The rare species were also found in Msr, MSf, FS, FB-Cn, FB-Csn, FBm and FBsn sites, but their numbers per plot are lower. Rare species were absent in pasture and ruderal habitats. Instead, alien species were present in $\mathrm{FB}-\mathrm{Cd}$, $\mathrm{Mp}$ [FB-C], FBsn, Mh and $\mathrm{Mp}$ [FB] sites. Ruderal habitats had the highest number of non-native species.

\section{Comparison of studied habitats}

The relationships between vegetation types were reflected in the dendrogram of a hierarchical cluster analysis using Euclidean Distance, which reflects the similarity of studied vegetation types (Fig. 7). Vegetation types in the dendrogram were clustered into five main groups. The first cluster includes natural beechconiferous, natural and modified beech forests FB-Cn, FBn and FBm. The second cluster contains degraded forest sites and secondary mead-

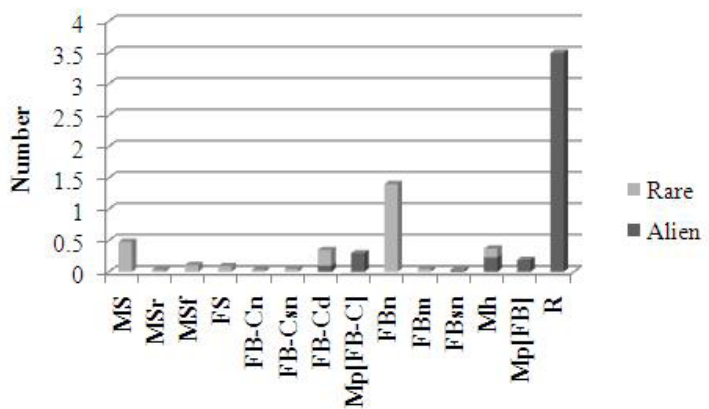

Fig. 7. Number of rare and alien species per studied sites $(N=$ 280).

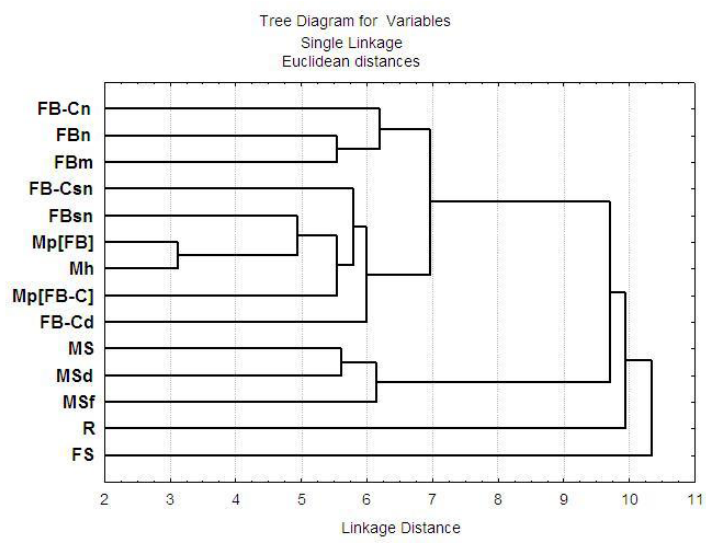

Fig. 8. Dendrogram of similarities of studied sites based on environmental factors.

ow communities FB-Csn, FBsn, $\mathrm{Mp}[\mathrm{FB}], \mathrm{Mh}, \mathrm{Mp}[\mathrm{FB}-\mathrm{C}]$ and FB-Cd, and the third - subalpine meadow communities MS, MSd and MSf (Fig. 8). The two separate clusters are formed by ruderal habitats (R) and subalpine forests (FS). This illustrates that different types of anthropogenic pressure influence coenosis structure changing their organisation and function. Apart from it, ecosystems of subalpine zone qualitatively differ from ecosystems of forest zones, and anthropogenic changes have different consequences in different altitude zones.

\section{Discussion and conclusion}

Our study revealed the quantitative changes in environmental conditions depending on altitude and anthropogenic disturbances. Along altitude gradient, increase in indices of soil humidity $(\mathrm{Hm})$, aeration $(\mathrm{Ae})$ and humidity $(\mathrm{Om})$, and decrease in soil acidity $(\mathrm{Rc})$, salt regime 
$(\mathrm{Sl})$, nitrogen content $(\mathrm{Nt})$ and temperature regime $(\mathrm{Tm})$ were observed. Under anthropogenic pressure, the indices of variability of damping $(\mathrm{fH})$, temperature regime $(\mathrm{Tm})$ and light in community $(\mathrm{Lc})$ increase, while soil aeration $(\mathrm{Ae})$ and humidity $(\mathrm{Om})$ decrease. Positive and negative correlations are established between environmental indices which determine the distribution of vegetation types, in particular differentiation between meadow and forest communities, as well as altitude differentiation.

The Shannon-Wiener index and species richness are important indicators of ecosystem changes. There are three key determinants of plant species diversity: competitive exclusion, disturbance processes and environmental heterogeneity (Connell, 1978; Peterson, Reich, 2008). Our findings in agreement with the disturbance hypothesis of Connell (1978) and Huston (1979) reveals: the highest species richness is expected in habitats with 'intermediate' disturbance level. Biodiversity indices varied among studied sites.

Habitat degradation and fragmentation facilitates distribution of invasive species in native coenoses while causing disappearance of native rare species.

Furthermore, presence of tree species and their canopy openness affects the spread of invasive species. The non-native species have not been observed in natural and in modified forests, as overstorey tree species create different understorey environmental conditions (Emery, Gross, 2006; Godefroid et al., 2005; Knight et al., 2008; Parrotta, 1995). Alien species are not distributed in high mountain zones, the specific conditions of which become a barrier to their distribution.

Therefore, anthropogenic pressure and altitude gradient influence indices of edaphic and climate conditions. However, anthropogenic pressure affects biodiversity. The highest species richness and Shannon-Wiener index are observed in habitats with 'intermediate' disturbances level (hay meadows, semi-natural forests), while high level of disturbances cause decrease in biodiversity (ruderal and pasture habitats, habitats under recreation pressure). The disturbances cause the ecosystem to become susceptible to invasion of alien species, while native species, especially rare, become vulnerable and can disappear.

Results of these studies are important for the development of nature conservation programmes, and also for prediction of ecosystem changes under anthropogenic disturbances and natural changes (in particular, climate).

\section{Acknowledgements}

We would like to express our thanks to Monika Janisova (Institute of Botany of Slovak Academy of Sciences) for her valuable comments on the manuscript.

\section{References}

Augustyn, M. (2004). Anthropogenic changes in the environmental parameters of the Bieszczady Mountains. Biosphere Conservation, 6, 43-53.

Badea, O., Bytnerowicz, A., Silaghi, D., Neagu, S., Barbu, I., Iacoban, C., Iacob, C., Guiman, G., Preda, E., Seceleanu, I., Oneata, M., Dumitru, I., Huber, V., Iuncu, H., Dinca, L., Leca, S. \& Taut I. (2012). Status of the Southern Carpathian forests in the long-term ecological research network. Environ. Monit. Assess., 184, 7491-7515. DOI: 10.1007/ s10661-011-2515-7.

Bálint, M., Ujvárosi, L., Theissinger, K., Lehrian, S., Mészáros, N. \& Pauls S.U. (2011). The Carpathians as a Major Diversity Hotspot in Europe. Biodiversity Hotspots (pp. 189-205). Berlin: Springer. 
Bennet, G. (2000). Ecoregion-Based Conservation: The Carpathians: Final Reconnaissance Report. Vienna: WWF-International Danube-Carpathian Programme.

Bihun, Yu. (2005). Principles of sustainable forest management in the framework of regional economic development. Visnyk Lviv Univ Ser. Geogr., 32, 19-32.

Bonan, G.B. (2008). Forests and climate change: forcings, feedbacks, and the climate benefits of forests. Science, 320, 1444-1449. DOI: 10.1126/science.1155121.

Bowen, M.E., McAlpine, C.A., House, A.P.N. \& Smith G.C. (2007). Regrowth forests on abandoned agricultural land: a review of their habitat values for recovering forest fauna. Biol. Conserv., 140, 273-296. DOI: 10.1016/j.biocon.2007.08.012.

Brunet, J., Fritz, O. \& Richnau G. (2010). Biodiversity in European beech forests - a review with recommendations for sustainable forest management. Ecol. Bull., 53, 77-94.

CEI (Carpathian Ecoregion Initiative) (2001). The Status of the Carpathians: A Report Developed as Part of the Carpathian Ecoregion Initiative. Vienna: World Wildlife Fund-International.

Chazdon, R.L. (2008). Beyond deforestation: restoring forests and ecosystem services on degraded lands. Science, 320, 1458-1460. DOI: 10.1126/science.1155365.

Connell, J.H. (1978). Diversity in tropical forests and coral reefs. Science, 199, 1302-1310. DOI: 10.1126/science.199.4335.1302.

Cutko, A. (2009). Biodiversity Inventory of Natural Lands: A How-To Manual for Foresters and Biologists. Arlington, Virginia: NatureServe.

Denisiuk, Z. \& Stoyko S.M. (2000). The East Carpathian biosphere reserve (Poland, Slovakia, Ukraine). In A. Breymeyer \& P. Dabrowski (Eds.), Biosphere reserves on borders (pp 79-93). Warsaw: UNESCO.

Didukh, Ya. P. (2011). The ecological scales for the species of Ukrainian flora and their use in synphytoindication. Kiev: Phytosociocentre.

Dufrene, M. \& Legendre P. (1997). Species assemblages and indicator species: the need for a flexible asymmetrical approach. Ecol. Monogr., 67, 345-366. DOI: 10.1890/0012-9615(1997)067[0345:SAAIST]2.0.CO;2.

Emery, S.M. \& Gross K.L. (2006). Dominant species identity regulates invasibility of old-field plant communities. Oikos, 115, 549-558. DOI: 10.1111/j.2006.0030-1299.15172.x.

Godefroid, S., Phartyal, S.S., Weyembergh, G. \& Koedam N. (2005). Ecological factors controlling the abundance of non-native invasive black cherry (Prunus serotina) in deciduous forest understory in Belgium. For. Ecol. Manag., 210, 91-105. DOI: 10.1016/j.foreco.2005.02.024.

Herenchuk, K. (1981). Nature of Zakarpatska Oblast (Transcarpathia). Lviv: Vyshcha Shkola Publishing House.

Honnay, O., Jacquemyn, H., Bossuyt, B. \& Hermy M. (2005). Forest fragmentation effects on patch occupancy and population viability of herbaceous plant species. New Phytol., 166(3), 723-736. DOI: 10.1111/j.1469-8137.2005.01352.x.

Huston, M. (1979). A general hypothesis of species diversity. Amer. Natur., 113, 81-101. http://www.jstor.org/stable/2459944

Kalutsky, I.F. (2008). The forest biocenosis of the Ukrainian Carpathian mountains, the problems of their conservation and sustainable development. Proceedings Forest Academy of Sciences of Ukraine: collection of scientific papers, 6, 55-60.

Knight, K.S., Oleksyn, J., Jagodzinski, A.M., Reich, P.B. \& Kasprowicz M. (2008). Overstory tree species regulate colonization by native and exotic plants: a source of positive relationships between understorey diversity and invasibility. Divers Distrib., 14, 666-675. DOI: 10.1111/j.1472-4642.2008.00468.x.

Krebs, C. (1978). Ecology: the experimental analysis of distribution and abundance. New York: Harper \& Row Publishers.

Krynytsky, G.T. \& Kramarets V.O. (2009). System of forestry measures on elimination of consequences of mass decline of spruce stands in beech-fir forests of Carpathians. Forestry and agroforestry: Coll. Science. Works, 115, 256-260.

Kuemmerle, T., Hostert, P., Radeloff, V.C., van derLinden, S., Perzanowski, K. \& Kruhlov I. (2008). Cross-border Comparison of Post-socialist Farmland Abandonment in the Carpathians. Ecosystems, 11, 614-628. DOI: 10.1007/ s10021-008-9146-z.

Kuemmerle, T., Chaskovskyy, O., Knorn, J., Kruhlov, I., Radeloff, V.C., Keeton, W.S. \& Hostert P. (2009). Forest cover change and illegal logging in the Ukrainian Carpathians in the transition period from 1988 to 2007. Remote Sens. Environ., 113, 1194-1207. DOI: 10.1016/j.rse.2009.02.006.

Lyons, K.G. \& Schwartz M.W. (2001). Rare species loss alters ecosystem function - invasion resistance. Ecol. Lett., 4, 358-365. DOI: 10.1046/j.1461-0248.2001.00235.x.

Mosyakin, S.L. \& Fedoronchuk M.M. (1999). Vascular plants of Ukraine. A nomenclatural checklist. Kiev: M.G. Kholodny Institute of Botany. 
Naeem, S. (2006). Biodiversity and ecosystem functioning in restored ecosystems: extracting principles for a synthetic perspective. In D.A. Falk, M.A. Palmer \& J.B. Zedler (Eds.), Foundations of restoration ecology (pp. 210-237). Washington: Island Press. National Atlas of Ukraine (2008). Kiev,

Parrotta, J.A. (1995). Influence of overstory composition on understory colonization by native species in plantations on a degraded tropical site. J. Veg. Sci., 6(5), 627-636. DOI: 10.2307/3236433.

Peet, P.K. (1974). The measurement of species diversity. Annu. Rev. Ecol. Syst., 5, 285-307. DOI: 10.1146/annurev. es.05.110174.001441.

Peterson, D.W. \& Reich P.B. (2008). Fire frequency and tree canopy structure influence plant species diversity in a forest-grassland ecotone. Plant Ecol., 194, 5-16. DOI: 10.1007/s11258-007-9270-4.

Rudel, T.K., Coomes, O.T., Moran, E., Achard, F., Angelsen, A., Xu, J.C. \& Lambin E. (2005). Forest transitions: towards a global under-standing of land use change. Global Environmental Change, 15, 23-31. DOI: 10.1016/j.gloenvcha.2004.11.001.

Solomakha, V.A. (2008). Syntaxonomy of the vegetation of Ukraine. Kiev: Fitosociocentre.

Standovár, T. \& Kenderes K. (2003). A review on natural stand dynamics in beechwoods of East Central Europe. Applied Ecology and Environmental Research, 1, 19-46.

Stohlgren, T.J., Barnett, D., Flather, C., Kartesz, J. \& Peterjohn B. (2005). Plant species invasions along the latitudinal gradient in the United States. Ecology, 86, 2298-2309. DOI: 10.1890/04-1195.

Turnock, D. (2002). Ecoregion-based conservation in the Carpathians and the land-use implications. Land Use Policy, 19, 47-63. DOI: 10.1016/S0264-8377(01)00039-4.

USAID (2001). Biodiversity Assessment for Ukraine: Task Order under the Biodiversity and Sustainable Forestry IQC (BIOFOR). Washington: Chemonics International Inc., Environment International Ltd.

Usckiy, I.M. (2010). Reasons and distributions of pathological processes in the fir-groves of Ukraine. Journal of KhNAU, $5,165-171$. 